\title{
Analyzing The Perspective of Halal Tourism Development : City Branding in Jakarta
}

\author{
Genoveva \\ School of Business \\ President University \\ Cikarang, Indonesia \\ genoveva@presidentac.id
}

\author{
Igbal Muhammad Kamal \\ School of Business \\ President University \\ Cikarang, Indonesia
}

iqbal.kamal.muhammad97@gmail.com

\begin{abstract}
Indonesia as the world's largest Muslim country has enormous opportunities in developing halal tourism. Jakarta as the capital which is the gateway for foreign tourists can easily introduce halal tourism as part of a tour. However OIC (Organization Islamic Cooperation) data shows that Indonesia is in second place for halal tourism, while Malaysia is in first place. This research aims to analyze the perspective of halal tourism development in Jakarta by using city branding theory proposed by Kavaratzis. The variables incorporated in this research were Landscape strategy, City's behavior, Organizational structure and Infrastructure. Jakarta as one of the cities prepared and developed by Indonesia Government as halal tourism destination in Indonesia cannot attract more Muslim tourists. By August 2018, most foreign visitors that came to Jakarta were tourists from non-Muslim countries. It means, Jakarta needs a new city branding strategy in order to be successful in developing halal tourism and also attracts more Muslim tourists both local and international. This research employed multiple regression. A total of 155 respondents were collected using purposive and non-probability sampling. Based on the result of the adjusted $R$ square, 58.3 percent of city branding development of halal tourism can be explained by all the independent variables, whereas the remaining 41.7 percent were influenced by other variables that were not included in this research. Furthermore, city's behavior, organizational structure and infrastructure have significant effects towards the city branding development of halal tourism in Jakarta.
\end{abstract}

Keywords- Landscape strategy, City's behavior, Organizational structure, Infrastructure, Development of Halal Tourism

\section{INTRODUCTION}

Indonesia as the country with religious and cultural diversity has a legacy of history and tradition that is connected inseparably with religious aspects and the religious practices of the community (7). In additional, Indonesia also as the largest Muslim in the worl's, however OIC (Organization Islamic Cooperation) data shows that Indonesia is in second place for halal tourism, while Malaysia is in first place (table I). Since 2013 the tourism minister launched halal tourism as one of the targets to reach more tourists, Jakarta has become as one of twelve province that designated for halal tourism destinations.

In terms of city branding for halal tourism, Jakarta is among the top priorities. There are several reasons behind the selection of the capital city for halal tourism destination in Indonesia. Firstly, according to Halaltourism (15), Jakarta is the seat of the national and the provincial government, and also Indonesia's political center. The second reason is that according to Indonesia Tourism Minister, Arief Yahya, stated that many Muslim tourists, especially from Saudi Arabia, visited Jakarta (16). Yahya (17) also said, around 160,000 of the total 180,000 Saudi Arabian tourists came to Indonesia through Jakarta. The third reason is that Jakarta has many big shopping centers of international class, such as Muslim clothing at Thamrin City, ITC Mangga Dua, ITC Kuningan, Ambassador Kuningan, Grand Indonesia, and many more (17). These conditions supported by Uno, as the Deputy Governor of Jakarta, stated that by 2020 Jakarta must be able to become one of the halal tourism destinations (18).

TABLE I. TOP TEN OIC DESTINATION

\begin{tabular}{|c|c|c|c|}
\hline Rank & GMTI 2018 Rank & Destination & Score \\
\hline 1 & 1 & Malaysia & 80.6 \\
\hline 2 & 2 & Indonesia & 72.8 \\
\hline 2 & 2 & United Arab Emirates & 72.8 \\
\hline 4 & 4 & Turkey & 69.1 \\
\hline 5 & 5 & Saudi Arabia & 68.7 \\
\hline 6 & 6 & Qatar & 66.2 \\
\hline 7 & 8 & Bahrain & 65.9 \\
\hline 8 & 9 & Oman & 65.1 \\
\hline 9 & 10 & Morocco & 61.7 \\
\hline 10 & 11 & Kuwait & 60.5 \\
\hline
\end{tabular}

Source : Mastercard \& Crescentrating (2018)

To support Jakarta as a destination for halal tourism, it needs to be improved in various ways. This improvement is expected to provide new city branding (Purwanti \& Genoveva, 2017). City Branding is a strategy to create a strong position of a city in terms of its brand image in the minds of their target market so that the city can be widely known throughout the country and the world (1). With a strong city brand, the city will have a confidence to develop its potentials, such as its tourism sector. According to Siswoprasetijo as a Chief Executive of PATA (Pacifisc Asia Travel Association) Indonesia, through a strong city branding, a city can conserve its natural and cultural assets (2).

The image of a city and its iconic buildings can influence visitors' perceived prosperity of its residents (3). However, nowadays, there is a competition between different cities to create their own brand image with the intention to attract visitors, investors and companies. Basically, every city has a brand. This brand acts as a competitive advantage that helps 
distinguishing the city from the rest. City brand is not only related to an image or logo, but other aspects considered to be valuable by its residents.

There are several things that must be considered by a local government in creating the image of the city, such as how cultural and history of the city, environment and landscape, architecture and infrastructure, as well as social development and economic growth can be converted into its identity or values which can be marketed and accepted by everyone (4). According to Mazilu and Lazar (5), landscape strategy has a positive effect towards the improvement of a tourism's place. According to Yu-Min and Bokyong (6), city's behavior and organizational structure have significant impacts on the development of tourism facilities. Additionally, according to Alwafi (7), infrastructure has a significant influence towards the development of halal tourism.

\section{LITERATURE REVIEW}

\section{A. City Branding}

City branding is a managerial plan that offers a particular city with a different identity, by giving the opportunity to appear different and positive so that it can be distinguished from its competitors (20). In today's increasingly competitive global competition, city branding could help a city attract visitors, residents, and even large amounts of funds so that this could contribute to diverse economic uses, social cohesion, and also generate added value for each city as a whole (21). Basically, the branding of a city is similar to branding a product or a service. However, city branding encompasses a much larger audience not limited to its residents but also visitors of the city; city branding aims to project values or an image that is unique to the city.

\section{B. Primary Communication Of City Branding}

According to Kavaratzis (22), primary communication of city branding is related with the communicative effect of city's action. Primary communication of city branding consists of 4 broad components, which are Landscape Strategy, City's Behavior, Organizational Structure, and Infrastructure.

The landscape strategy is based on interventions that are relevant to the design of the city, the architecture of urban buildings, and also the public space in the city (23). In addition, landscape strategy also incorporates the use of public art and heritage management. The indicator of landscape strategy factors are urban design, architecture, public space, and public art (22). According to Ashworth (23), City's behavior in this case means exploring the quality of services provided by the city, the type and scale of events held in the city. In addition, behavior also explores the city vision created by its leaders and also the financial incentives provided. The indicator of behavior factors are vision for the city, quality of services, events, and financial incentive (22).

Kavaratzis (22) stated that the organizational structure in this case also describes how private public partnerships, community development networks and citizen participation in decision making. The indicator of organizational factors are community networks, public private partnership, and citizens' participation (22). According to Ashworth (23) infrastructure determine projects developed by the city to create, enhance or provide special characters for various types of infrastructure, whether increasing accessibility to the city or improving adequate facilities. The indicator of infrastructure factors are accessibilities, cultural facilities and tourism facilities (22).

\section{Development of Halal Tourism}

According to Battour and Nazari (24), halal tourism could be summarized as any touristic object or action that is permissible and is based on Islamic teachings. The most important aspect of the term halal tourism is the word "halal" itself. Halal means everything that is permitted and allowed in accordance with the Holy Qur'an. Therefore, developing and marketing a halal tourism must be based on the application of the principles of Islam.

Mohsin, Ramli and Alkhulayfi (25) also stated halal tourism could be developed very well in a country if the hospitality industry can offer halal food and facilities suitable for Muslim tourists. According to Palupi, Arifan and Romadhon (26), there are several factors that could influence the success in developing halal tourism industry, which are the availability of halal accommodation, the availability of halal food and beverages, human capital, and continuous innovation.

\section{Research Gap}

Most of researches only examine and identify the city branding towards the conventional tourism or reconstruction of the city image. There is limited research in identifying the influence of city branding towards the development of halal tourism. The researchers were thus interested in conducting further research on the influence of city branding towards the development of halal tourism.

There are some research gaps between this research and previous researches. Firstly, previous research conducted by Yu-Min and Bokyong (6) focused on analyzing the influence of primary communication of city branding by Kavaratzis towards the tourism policy changes in Seoul. Meanwhile this research focused on the influence of primary communication of city branding by Kavaratzis towards the development of halal tourism in Jakarta.

Secondly, compare to Alwafi (7), his research focused on analyzing the city branding's strategy of Nusa Tenggara Barat in making Lombok as halal tourism destination using the qualitative method. Meanwhile, this research is focusing on the influence of city branding towards the development of halal tourism in Jakarta using quantitative method.

Lastly, previous research by Mazilu and Lazar (19) discussed the effect of cultural landscape towards the development of a sustainable conventional tourism. On the other hand, this research focused not only about the landscape but also city's behavior, organizational structure, and infrastructure towards the development of halal tourism in Jakarta.

\section{METHODOLOGY}

This research is a quantitative study using a questionnaire as a data collection tool. Based on Hair's (27) equations, there are 155 respondents for the first period, the researchers got 152 respodents for the second period, the total of respondents are 307, required to fill in the online 
questionnaires, as there are a total of 36 questions, 2 questions are considered as invalid. The data prossesed using SPSS version 23.0.

To determine the relationship between independent and dependent variables, the hypothesis is presented in this particular study as:

- Hypothesis 1: There is a significant influence of landscape strategy, city's behavior, organizational structure and infrastructure towards the city branding in the development of halal tourism.

- Hypothesis 2: There is a significance influence of city's behavior towards the city branding in the development of halal tourism

- Hypothesis 3: There is a significant influence of organizational structure towards the city branding in the development of halal tourism

- Hypothesis 4: There is a significant influence of infrastructure towards the city branding in the development of halal tourism

- Hypothesis 5: There is a significance influence of landscape strategy towards the city branding in the development of halal tourism

\section{RESULT AND DISCUSSION}

\section{A. Validity and Reliability}

The purpose of testing validity is to eliminate inappropriate questions in the questionnaire. In addition, the validity test is used to determine whether the questionnaire is valid or not. Pearson product-moment correlation coefficient (or Pearson correlation coefficient) is a measure of the strength of a linear relationship between two variables and denoted by $r$. The result of the validity test shows all statements in the questionnaire for every variable $\alpha$ used for this research are valid $(>0.361)(27)$ with $95 \%(\alpha)$ as the significant value.

The results of reliability test also show that all variables which are landscape strategy, city's behavior, organizational structure and infrastructure have high reliability $(>0.60)$ (27).

\section{B. F-Test}

The F-test was also used to analyze influence of all independent variables in this research, such as Landscape strategy factors, City's behavior factors, Organizational structure factors and Infrastructure factors on the development of halal tourism in Jakarta. The result of F-test of this research can be seen in table II.

According to F-Test Result, the hypothesis accepted is:

- Hypothesis 1: There is significant of landscape strategy, city's behavior, organizational structure and infrastructure towards the city branding in the development of halal tourism.
TABLE II. F-TEST

\begin{tabular}{|c|c|c|c|c|c|c|}
\hline \multicolumn{7}{|c|}{ ANOVA ${ }^{\mathrm{a}}$} \\
\hline \multicolumn{2}{|c|}{ Model } & $\begin{array}{l}\text { Sum of } \\
\text { Squares }\end{array}$ & df & $\begin{array}{l}\text { Mean } \\
\text { Square }\end{array}$ & $\mathrm{F}$ & Sig. \\
\hline \multirow[t]{3}{*}{1} & Regression & 576.869 & 4 & 144.217 & 54.743 & $.000^{b}$ \\
\hline & Residual & 395.170 & 150 & 2.634 & & \\
\hline & Total & 972.039 & 154 & & & \\
\hline
\end{tabular}

Source : Questionnaire, Processed by SPSS ver. 23.0

\section{T-test}

The $\mathrm{T}$ - test determines whether or not independent variables have a significant partial influence on the dependent variable. To find out which variable has a significant influence, the significant score should be $<0.05$, the score can be seen in the table III below :

TABLE III. T-TEST

\begin{tabular}{|c|l|r|r|r|r|r|}
\hline \multicolumn{2}{|c|}{ Model } & \multicolumn{2}{|c|}{$\begin{array}{c}\text { Unstandardized } \\
\text { Coefficients }\end{array}$} & $\begin{array}{c}\text { Standardized } \\
\text { Coefficients }\end{array}$ & \multicolumn{1}{c|}{ t } & \multicolumn{1}{c|}{ Sig. } \\
\cline { 3 - 5 } \multicolumn{2}{|c|}{} & \multicolumn{1}{|c|}{ B } & Std. Error & \multicolumn{1}{|c|}{ Beta } & & \\
\hline \multirow{3}{*}{1} & (Constant) & 1.872 & 1.089 & & 1.719 & .088 \\
& TLS & .007 & .041 & 0.11 & .171 & .865 \\
& TCB & .453 & .054 & .568 & 8.398 & .000 \\
& TOS & .122 & .061 & .139 & 2.014 & .046 \\
& TINF & .162 & .073 & .161 & 2.217 & .028 \\
\hline
\end{tabular}

Source : Questionnaire, Processed by SPSS ver. 23.0

According to T-Test Result, the hypothesis result are as follows:

- Hypothesis 2: There is no significant influence of Landscape Strategies towards the development of halal tourism in Jakarta

- Hypothesis 3: There is significant influence of City's Behavior towards the development of halal tourism in Jakarta

- Hypothesis 4: There is significant influence of Organizational Structure towards the development of halal tourism in Jakarta

- Hypothesis 5: There is significant Influence of Infrastructure towards the development of halal tourism in Jakarta.

The t-test concluded that, only hyphothesis 2 has no significant (Lanscape Strategies) on Halal Tourism in Jakarta.

D. Multiple Regression

The multiple regression model is presented as as follows:

$1.872=.007 \mathrm{TLS}+.453 \mathrm{TCB}+.122 \mathrm{TOS}+.162 \mathrm{TINF}$

Where:

$\mathrm{Y}=$ Development of Halal Tourism

TLS = Lanscape Strategy

TCB = City's Behavior

TOS = Organizational Structure

TINF $=$ Infrastructure 
From table III above, it can be concluded that the variable that most influences Jakarta as a city branding in the development of halal tourism is City Behavior (45.3\%).

\section{E. Coefficient Corelations}

Results calculated using SPSS 23.0 shown that the adjusted $\mathrm{R}$ square value is 0.583 . It means that $58.3 \%$ of the development of halal tourism are contributed by Landscape strategy, the City's behavior, the Organizational structure and the Infrastructure variables. Whereas the remaining $41.7 \%$ of halal tourism development is influenced by other variables that have not been included in this research.

Table IV also shows that there is a strong correlation between independent and dependent variables which is $77 \%$ $(>0.50 \%)(27)$.

TABLE IV. COEFFICIENT CORRELATION

\begin{tabular}{|c|c|c|c|c|c|}
\hline \multicolumn{6}{|c|}{ Model Summary ${ }^{\mathrm{b}}$} \\
\hline Model & $\mathrm{R}$ & R Square & $\begin{array}{c}\text { Adjusted } R \\
\text { Square }\end{array}$ & $\begin{array}{l}\text { Std. Error of } \\
\text { the Estimate }\end{array}$ & $\begin{array}{l}\text { Durbin- } \\
\text { Watson }\end{array}$ \\
\hline 1 & $.770^{\mathrm{s}}$ & .593 & .583 & 1.62310 & 2.047 \\
\hline
\end{tabular}

\section{CONCLUSION AND RECOMMENDATION}

\section{A. Conclusion}

The result of F-Test based on the table II there are significant influence of Landscape strategy factors, City's behavior factors, Organizational structure factors and Infrastructure factors towards the development of halal tourism in Jakarta (Y) with 0.000 as its significance values and below 0.05 .

These findings were also in line with a study conducted by Yu-Min \& Bokyong (6) which stated that Kavaratzis' primary communication of city branding consisting of Landscape strategy (X1), City's behavior (X2), Organizational structure (X3) and Infrastructure (X4) have significant influence towards the city branding of conventional tourism. This indicates that it is possible for the four variables to influence the development of halal tourism.

The results of hypothesis 2 tests have demonstrated that landscape strategy has no significant influence on the development of halal tourism in Jakarta with a significance value of 0.865 and more than 0.05 . This means that the development of halal tourism in Jakarta is not influenced by the strategy of landscape. Mazilu \& Lazar (5) stated that, landscape strategy should be part of city sustainability. Its mean that, Jakarta city landscape strategy should be part of city sustainability.

The results of hypothesis 3 tests have shown that the City's behavior has a significant influence on the development of halal tourism in Jakarta with a significance value of 0.000 and less than 0.05 . This means that the development of halal tourism in Jakarta is influenced by the City's behavior.

As well as hypothesis 4 tests have shown that the Organizational structure has a significant influence on the development of halal tourism in Jakarta with a value of
0.046 and less than 0.05 in significance. This means that the development of halal tourism in Jakarta is influenced by the Organizational structure. As mentioned by Yu-Min \& Bokyong (6) organizational structure has a significant influence on the development of tourism. As a result of the research carried out by Yu-Min \& Bokyong (6) along with city's behavior, organizational structure has a significant influence on the development of tourism and changes in the policy of tourism in Seoul. It means that organizational structure also can influence the development of tourism's generally in Indonesia, and as specifically organizational structure also can influence the development of halal tourism in Indonesia.

The results of hypothesis 5 tests have demonstrated that Infrastructure has a significant influence on the development of halal tourism in Jakarta, with a value of 0.028 and less than 0.05 in significance. This means that infrastructure influences the development of halal tourism in Jakarta.

As Alwafi (7) mentioned, infrastructure has a significant influence on the development of halal tourism. Result of the research carried out by Alwafi (7) one of the city branding strategies used by the West Nusa Tenggara Government to make Lombok as a halal tourism destination, is marketing infrastructure. It means that infrastructure marketing also can influence the development of halal tourism in Jakarta.

\section{B. Recommendation}

According to the result of the T-Test, city's behavior has a level of significance .000 that is lower from the others variables' significance level. In terms of Multiple Regression Model, city's behavior is able to increase the development of halal tourism in Jakarta by $45.3 \%$. From these results, DKI Jakarta Government must pay attention on the indicators of city's behavior, such as: vision for the city, quality of services, events and also financial incentives in implementing the city branding towards the development of halal tourism in Jakarta.

In order to attract local and foreign Muslim tourists who want to visit Halal tourism in Jakarta, the government must pay attention to public facilities such as hotels, shopping centers, airports and tourist facilities, which must be equipped with Muslim facilities, such as the availability of prayer rooms, the availability of Halal food and beverages $(6,7)$

Maximize the existence of Jakarta to enhance communication between the Government and the people of Jakarta. This segmentation supports the success of the city branding in Jakarta in the development of halal tourism so that the population can increase ownership of the city and participate in the successful development of halal tourism in Jakarta.

The researchers would like to recommend future researchers to use other variables that might influence to development Halal Tourism, namely Culture Value, Empowering Local Community (11), Safety and Convort, Respect to social culture and local wisdom (28). It is very interesting if the future researchers are interested in doing a research about halal tourism. It will also be better if the future research put more demographic question and bigger population in conducting the research. 


\section{REFERENCES}

[1] Yanti, S., Susanne, D., \& Ni Putu, C. U. (2018). City Branding of Denpasar City. Emerald Insights, 369.

[2] Hamdani, S. (2015, May 31). 'City Branding' to Boost Tourism in Indonesia. Retrieved from Jakarta Globe: http://jakartaglobe.id

[3] Müge, R., Naciye, D., \& Mukaddes, F. (2012). City Branding and Identity. Elsevier SciVerse SienceDirect, 294

[4] Zhang \& Zhao (2009). City branding and the Olympic effect: A case study of Beijing . Elsevie : Cities. Vol. 26. p. 245-254.

[5] Mazilu, M., \& Lazar, I. (2014). The Cultural Landscape: Perception, Knowledge, Awareness and Support to The Development of A Sustainable Tourism. Addleton Academic Publisher, p.123-131.

[6] Yu-Min, J., \& Bokyong, S. (2017). Transformative City Branding for Policy Change: The Case of Seoul's Participatory Branding. Sage, p.239-257.

[7] Alwafi, R. S. (2017). Strategi City Branding Nusa Tenggara Barat Menjadikan Lombok Sebagai Destinasi Pariwisata Halal. UMM Institutional Repository,p. 1-91.

[8] Rakhmat, M. Z. (2016, 10 3). Halal Tourism: An Important Idea In Tourism Industry. Retrieved from Huffington Post: https://www.huffingtonpost.co.uk

[9] Ghazali, M., Suhana, B. M., \& Sedigheh, M. (2017). UNDERSTANDING ISLAMIC (HALAL) TOURISM THROUGH LEIPER'S TOURISM SYSTEM. ReserachGate, 3.

[10] Jaelani. (2016). Religious heritage tourism and creative economy in Cirebon: The diversity of religious, cultures, and culinary. Journal of Social and Administrative Sciences, p.63-76.

[11] Jaelani, A. (2017). Halal Tourism Industry in Indonesia: Potential and Prospects. Econjournals, International Review of Management adn Marketing. Vol. 7 (3). p. 25-34.

[12] Mastercard, \& Crescentrating. (2018). Global Muslim Travel Index 2018. Bukit Merah, Singapore: Mastercard \& Crescent Rating.

[13] Atang, A. H., Hasan, R., Hasanuddin, M., \& Sofian, A.-H. (2017). Towards Indonesia Halal Tourism. Ahkam Jurnal Ilmu Syariah. Vol. 7(2). p.279-300.

[14] Azhar, R. (2018, January 10). Indonesia Ranks 4th in Halal Tourism Indicator. Retrieved from Now Jakarta: http://nowjakarta.co.id

[15] Halaltourism, I. (2019). Great Jakarta. Retrieved from Halal Tourism Indonesia Web site: http://halaltourism.id
[16] Prodjo, W. A. (2017, November 3). Menpar: Jakarta Masuk Top 5 Pengembangan Wisata Halal di Indonesia. Retrieved from KOMPAS.com: http://travel.kompas.com

[17] Yahya, A. (2017, November 3). Menpar: Jakarta Masuk Top 5 Pengembangan Wisata Halal di Indonesia. Retrieved from Kompas.com Website: https://travel.kompas.com

[18] Uno, S. (2018, March 12). Jakarta, Pintu Masuk Wisata Halal Indonesia. Retrieved from WormTraders: https://wormtraders.com

[19] Mazilu, M., \& Lazar, I. (2014). The Cultural Landscape: Perception, Knowledge, Awareness and Support To The Development of Sustainable Tourism. Addleton Academic Publisher,. P.123-131.

[20] Ali, S. (2017). Exploring city branding strategies and their impacts on local tourism success, the case study of Kumamoto Prefecture, Japan. Asia Pacific Journal of Tourism Research, 1.

[21] Marko, P., Zoran, F., \& Željko, S. (2010). Methodology of Valuation of Cities' Brands. Economic Research. p.102-111.

[22] Kavaratzis, M. (2009). Cities and their brands: Lessons from corporate branding. Place Branding and Public Vol.5 (1). P.26-37.

[23] Ashworth. (2007). Beyond the logo: Brand management for cities. Research Gate, 527.

[24] Battour, M., \& Nazari Ismail, M. (2015). Halal tourism: Concepts, practises, challenges and future. Elsevier : Tourism Management Perspectives,.Vol.19. p. 150-154.

[25] Mohsin, A., Ramli, N., \& Alkhulayfi, A. B. (2016). Halal tourism: Emerging opportunities. Elsevier, : Tourism Management Perspectives. Vol. 19. p.137-143.

[26] Palupi, M., Arifan, N., \& Romadhon, W. R. (2017). The Importance of Optimization of Halal Tourism: A Study of development of Halal Tourism in Indonesia. Research Gate, p. 3-4.

[27] Sekaran, U., \& Bougie, R. (2016). Research Method For Business. 7th Edition. New York : John Wiley \& Sons 